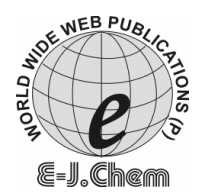

\title{
Simple Spectrophotometric Methods for the Determination of Sulfamethaxazole in Pharmaceuticals Using Folinciocalteau and Orcinol as Reagents
}

\author{
G VIJAYA RAJA*, C BALA SEKARAN", D. WINNIE TEJA ${ }^{\S}$, \\ B MADHURI $^{\S}$ and B JAYASREE ${ }^{\S}$
}

*Department of Biotechnology, Acharya Nagarjuna University, Guntur.

\#Department of Biotechnology,

P. B. Siddhartha College of Arts \& Science, Vijayawada - 520 010, India.

${ }^{\S}$ Department of Biotechnology,

P. B. Siddhartha College of Arts \& Science, Vijayawada - 520 010, India.

balumphil@gmail.com

Received 3 September 2008; Accepted 5 October 2008

\begin{abstract}
Two simple, sensitive and reproducible spectrophotometric methods (Method A and Method B) were developed for the determination of sulfamethaxazole in bulk and in dosage forms. Method A is based reduction of phosphomolybdic acid present in Folin Ciocalteau reagent by the drug sulfamethaxazole in the presence of sodium carbonate to form a blue colored chromogen having maximum absorption at $760 \mathrm{~nm}$. Method B is based on the diazotization of the drug by sodium nitrite in acidic medium at $5{ }^{\circ} \mathrm{C}$ followed by coupling with orcinol to form yellow colored species $\left(\lambda_{\max } 390 \mathrm{~nm}\right)$. Beer's law is obeyed in the range of $5-25 \mu \mathrm{g} / \mathrm{mL}$ for method A and $2-10 \mu \mathrm{g} / \mathrm{mL}$ for method B. Results of analysis were validated statistically and by recovery studies. These methods are successfully employed for the determination of sulfamethaxazole in various pharmaceutical preparations and biological fluids.
\end{abstract}

Keywords: Sulfamethaxazole (SFZ), Sandell's sensitivity visible, Spectrophotometric determination, Beer's Law.

\section{Introduction}

Sulfamethoxazole is a sulfonamide bacteriostatic antibiotic. Sulfonamides are structural analogs and competitive antagonists of para-aminobenzoic acid (PABA). They inhibit normal bacterial utilization of PABA for the synthesis of folic acid, an important metabolite in DNA synthesis ${ }^{1,2}$ are used in the treatment of urinary track infections, eye infections and 
as a prophylaxis of rheumatic fever ${ }^{3}$. The drug has been determined by a variety of analytical techniques such as high performance liquid chromatography ${ }^{4,5}$, high performance thin layer chromatography ${ }^{6}$, gas chromatography ${ }^{7}$, electroanalytical methods ${ }^{8-11}$, spectrophotometry ${ }^{12-16}$ and differential scanning calorimetry ${ }^{17}$. In the present study the authors had developed two simple and sensitive spectrophtometric methods for the determination of SFZ in pharmaceutical formulations and biological samples.

\section{Experimental}

\section{Apparatus}

- $\quad$ Systronics UV - Visible Double beam spectrophotometer model 2201.

All the chemicals used were of analytical grade. All the solutions were freshly prepared in distilled water.

- Folin Ciocalteau reagent: This reagent is commercially available. The original stock reagent was diluted to 1:2 ratios with water (Method A).

- $20 \%$ Sodium carbonate: Prepared by dissolving $20 \mathrm{~g}$ of sodium carbonate in 100 $\mathrm{mL}$ of distilled water (Method A).

- $\quad 0.1 \%$ Sodium nitrite: Prepared by dissolving $100 \mathrm{mg}$ of sodium nitrite in $100 \mathrm{~mL}$ of distilled water (Method B).

- $5 \mathrm{~N} \mathrm{HCl}($ Method B)

- $0.2 \%$ Orcinol: Prepared by dissolving $200 \mathrm{mg}$ of orcinol in $100 \mathrm{~mL}$ of distilled water (Method B)

\section{Preparation of standard and sample solution}

Accurately weighed $100 \mathrm{mg}$ of SFZ was dissolved in $2 \mathrm{~mL}$ of $10 \mathrm{M} \mathrm{H}_{2} \mathrm{SO}_{4}$ and made up to $100 \mathrm{~mL}$ with distilled water to give a concentration of $1 \mathrm{mg} / \mathrm{mL}$. The final concentration was brought to $100 \mu \mathrm{g} / \mathrm{mL}$ for method A and $200 \mu \mathrm{g} / \mathrm{mL}$ Method B.

\section{General procedure for the determination of sulfamethaxazole}

\section{Method A}

Aliquots of the working standard solution of SFZ $(100 \mu \mathrm{g} / \mathrm{mL})$ were transferred into a series of $10 \mathrm{~mL}$ calibrated flasks. To all the flasks $1 \mathrm{~mL}$ of 1:2 diluted Folin Ciocalteau reagent and $2 \mathrm{~mL}$ of $20 \%$ sodium carbonate were added. The solution was made up to the mark with distilled water, mixed well and kept aside for $20 \mathrm{~min}$. The absorbance of the blue colored solution was measured at $760 \mathrm{~nm}$ against the corresponding reagent blank.

\section{Method B}

Aliquots of working standard solution of SFZ solutions $(200 \mu \mathrm{g} / \mathrm{mL})$ were transferred into $10 \mathrm{~mL}$ calibrated flasks followed by $2.0 \mathrm{~mL} 5 \mathrm{~N} \mathrm{HCl}$ to each. After cooling in an ice bath, $2 \mathrm{~mL}$ of $1 \%$ sodium nitrite was added under swirling. The solutions were allowed to stand for 5 min and then $1 \mathrm{~mL}$ of $0.2 \%$ orcinol was added. The solution was made up to the mark with distilled water, mixed thoroughly and after $5 \mathrm{~min}$ the absorbance was measured at $390 \mathrm{~nm}$ against a reagent blank, and the calibration graph was constructed.

\section{Assay of pharmaceutical tablets}

Twenty tablets were powdered and mixed thoroughly. An amount equivalent to $100 \mathrm{mg}$ of the SFZ was dissolved in water and filtered. The filtrate was made up to $100 \mathrm{~mL}$ and appropriate aliquots of the drug solution were treated as described above for the determination of SFZ. 


\section{Results and Discussion}

\section{Spectral characteristics}

Method A involves the reduction of the phosphomolybdic acid by the SFZ in the presence of sodium carbonate. Method B involves the diazotization of SFZ, followed by coupling with orcinol. The absorption spectra of reduced phosphomolybdic acid and SFZ-orcinol complex have absorption maxima at 760 and $390 \mathrm{~nm}$ respectively.

\section{Analytical data}

The optical characteristics such as Beer's law limits, Sandell's sensitivity, molar absorptivity, percent relative standard deviation (calculated from six replicate samples) were calculated for all the methods and the results are summarized in Table 1. Regression characteristics like standard deviation of slope (b), standard deviation of intercept (a) and \% range of error ( 0.05 and 0.01 confidence limits) and were calculated for all the methods and are shown in Table 1.

Table 1. Optical and regression characteristics, precision and accuracy of the proposed methods.

\begin{tabular}{lll}
\hline \multicolumn{1}{c}{ Parameters } & Method A & Method B \\
\hline$\lambda_{\text {max }}, \mathrm{nm}$ & 760 & 390 \\
Beer's law limit, $\mu \mathrm{g} / \mathrm{mL}$ & $5-25$ & $2-10$ \\
Sandell's Sensitivity, $\mu \mathrm{g} / \mathrm{cm}^{2} / 0.001$ abs. unit & 0.01 & 0.017 \\
$\begin{array}{l}\text { Molar absorptivity, Litre.mole }{ }^{-1} . \mathrm{cm}^{-1} \\
\text { Stability of Color (hours) }\end{array}$ & $2.53 \times 10^{4}$ & $1.481 \times 10^{4}$ \\
$\begin{array}{c}\text { Regression equation (Y) } \\
\text { Intercept (a) }\end{array}$ & 48 & 24 \\
$\quad$ Slope(b) & 0.013 & 0.014 \\
\% RSD & 0.0090 & 0.005 \\
\% Range of errors, 95\% confidence limits: & 1.8 & 1.72 \\
$\quad 0.05$ significance level & 0.67 & 0.61 \\
$\quad 0.01$ significance level & 1.47 & 1.38 \\
\hline
\end{tabular}

${ }^{*} Y=a+b x$, where $Y$ is the absorbance and $x$ is the concentration of sulfamethaxazole in $\mu \mathrm{g} / \mathrm{mL} \$$ for six replicates

\section{Analysis of pharmaceutical preparations}

Application of the proposed methods to the determination of SFZ in its dosage forms was successfully made; the results are presented in Table 2. The excellent recoveries obtained indicated the absence of any interference from the excipients.

Table 2. Results of analysis of tablet formulations containing SFZ.

\begin{tabular}{|c|c|c|c|c|}
\hline \multirow[t]{2}{*}{ Formulations } & \multirow{2}{*}{$\begin{array}{c}\text { Labeled } \\
\text { amount, mg }\end{array}$} & \multirow{2}{*}{$\begin{array}{l}\text { Recovery by } \\
\text { reference method", \% }\end{array}$} & \multicolumn{2}{|c|}{$\begin{array}{l}\text { Recovery by proposed } \\
\text { methods }{ }^{* *}, \%\end{array}$} \\
\hline & & & Method A & Method B \\
\hline Tablet I & 100 & 99.90 & 99.95 & 99.96 \\
\hline Tablet II & 100 & 99.86 & 99.70 & 98.60 \\
\hline Tablet III & 100 & 98.76 & 99.80 & 99.69 \\
\hline
\end{tabular}

*Reference method was UV method developed in the laboratory.

*** Recovery amount was the average of six determinants. 


\section{Conclusions}

The proposed methods were found to be simple, economical, selective and sensitive. The statistical parameters and recovery study data clearly indicate the reproducibility and accuracy of the methods. Analysis of the authentic samples containing SFZ showed no interference from the common excipients. Hence, these methods could be considered for the determination of SFZ in the quality control laboratories.

\section{Acknowledgements}

The authors are grateful to the Acharya Nagarjuna University, Guntur and Management of Siddhartha Academy, Vijayawada for their continuous support and encouragement and for providing the necessary facilities.

\section{References}

1. Martindale, The extra pharmacopoeia, $30^{\text {th }}$ Ed., p. 208

2. Mitscher L A, Antibiotics and Antimicrobial Agents, Foye's Principles of Medicinal Chemistry, 2002, $5^{\text {th }}$ Ed., 819-862.

3. Petri W A Jr, Antimicrobial Agents, Goodman and Gilman's Pharmacological Basis of Therapeutics, 2001, 10 $0^{\text {th }}$ Ed., 1171- 1188.

4. El Anwar F M, El Walily A M, Abdel Hay M H and M. El Swify, Anal Lett., 1991, 24, 767-779.

5. Thomas G K, Millar R G and Antis P W, JAOAC Int., 1997, 80, 988-995.

6. Knupp G, Pollmann H and Jonas D, Chromatographia, 1986, 22, 21-24.

7. Chivarino B, Crestoni M A, Di-Marzio A and Fornarini S, J Chromatogr Biomed Appl., 1998, 706, 269-277.

8. $\quad$ Flurer C L, Electrophoresis, 1997, 18, 2427- 2437.

9. Malecki F and Starosak V, Anal Chim Acta, 1982, 139, 353-357.

10. Ackermans M T, Beckers J L, Everaerts F M, Hoogland H and Tomassen M J H, J Chromatogr., 1992, 596, 101-109.

11. Msagati T A M and Ngila J C, Talanta, 2002, 58, 605-610.

12. Nagaraja P, Sunitha K R, Vasantha R A and Yathirajan H S, Eur J Pharm Biopharm., 2002, 53, 187-192.

13. Nagaraja P, Yathirajan H S, Raju C R, Vasantha R A, Hemantha Kumar M S and Nagendra P, Farmaco, 2003, 58, 1295-1300.

14. Raghuveer S, Raju I R K, Vastu D K and Shrivastava C M R, Indian Drugs, 1993, 30, 132-135.

15. Amin A S and Zarch M M, Mikrochim Acta, 1996, 124, 227- 233.

16. Sabry S S, Anal Lett., 2006, 39, 2591-2615.

17. Issa Y M, Ansary A L El and Selim W, Anal Lett., 1998, 31, 131-146. 


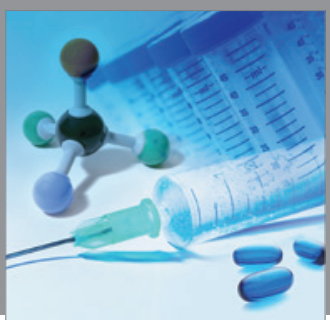

International Journal of

Medicinal Chemistry

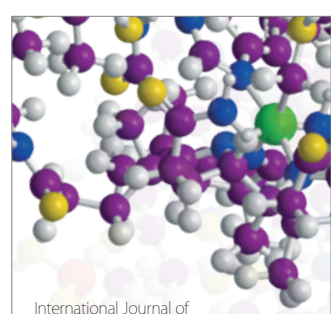

Carbohydrate Chemistry

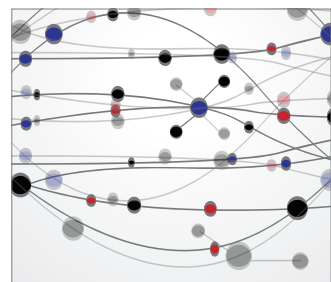

The Scientific World Journal
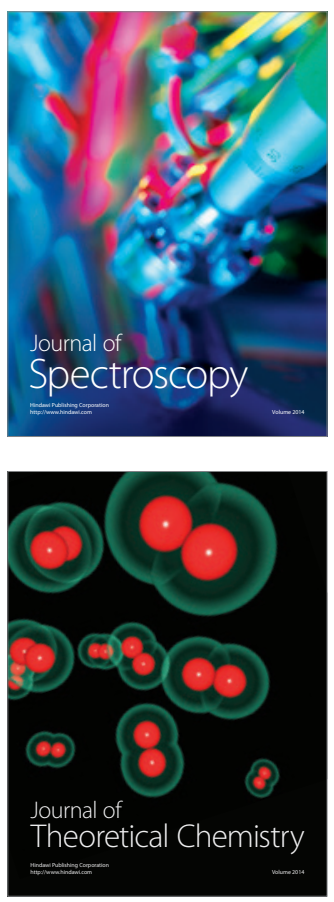
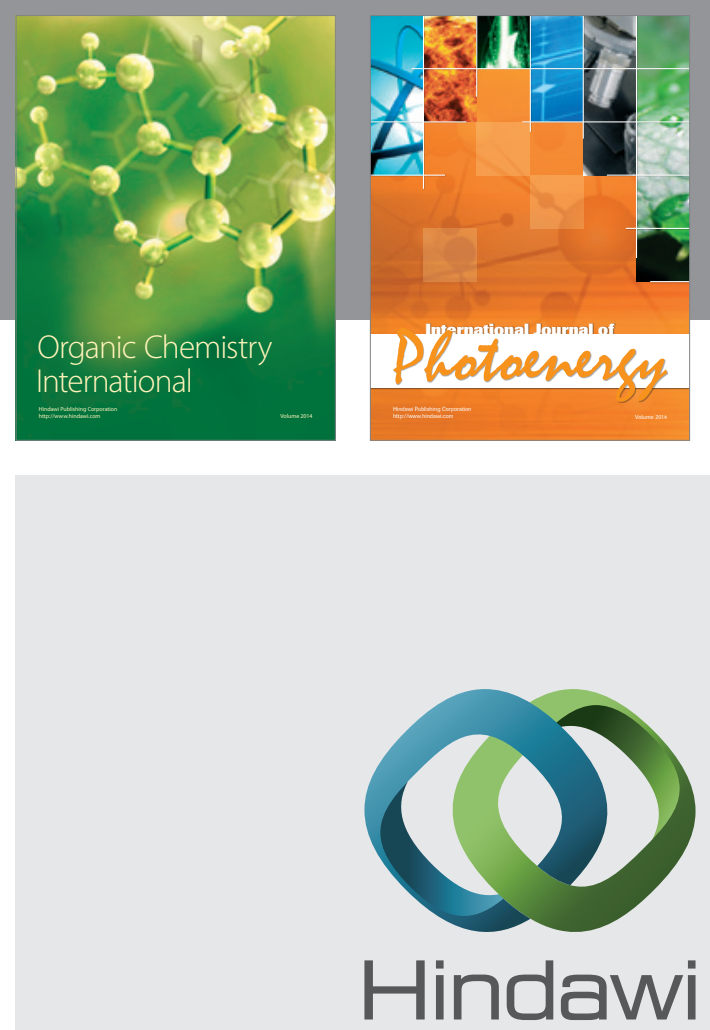

Submit your manuscripts at

http://www.hindawi.com
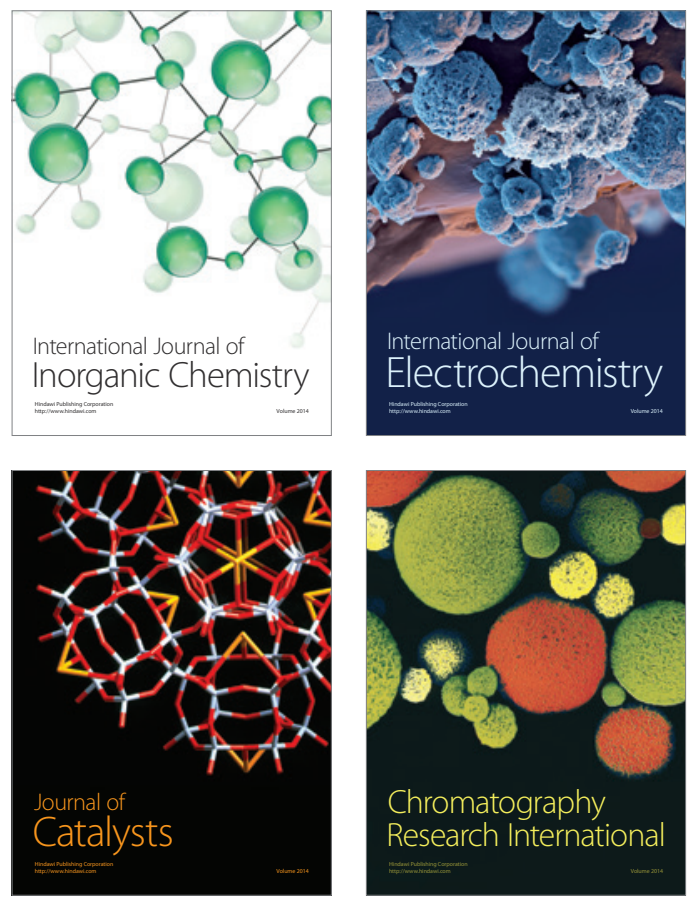
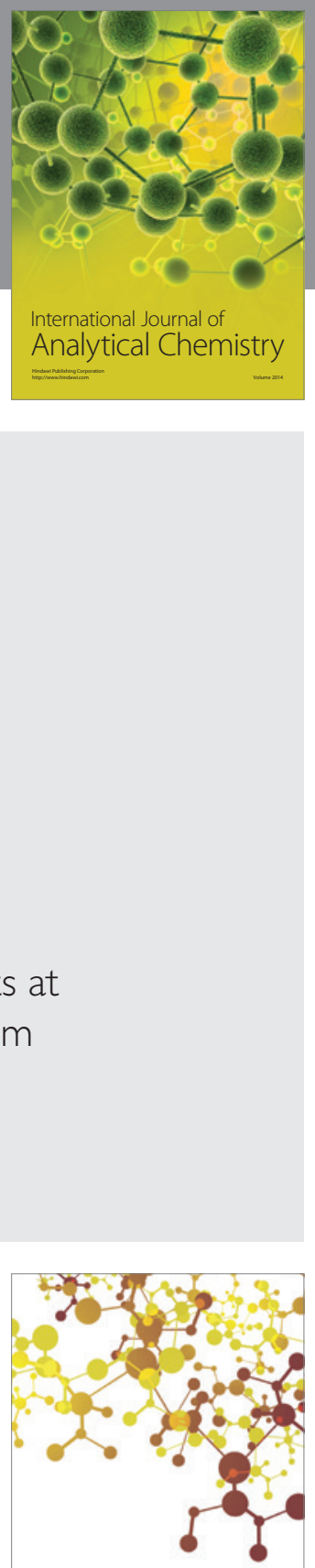

Journal of

Applied Chemistry
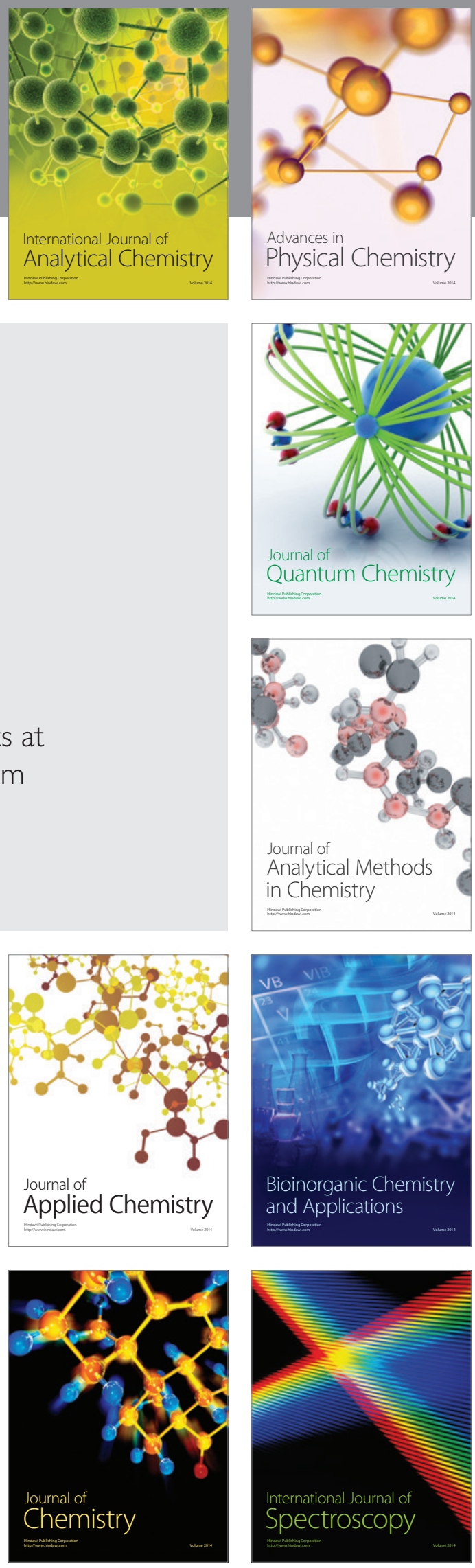